\title{
Vocal Control Region Sizes of an Adult Female Songbird Change Seasonally in the Absence of Detectable Circulating Testosterone Concentrations
}

\author{
Pierre Deviche, Cynthia C. Gulledge* \\ Institute of Arctic Biology, University of Alaska Fairbanks, Fairbanks, Alaska 99775-7000
}

Received 26 April 1999; accepted 26 July 1999

\begin{abstract}
Previous research established that in several species of seasonally breeding oscine birds, brain areas [vocal control regions (VCRs)] that control vocal behavior learning and expression exhibit seasonal plasticity, being larger during than outside the reproductive period. In adult males, this seasonal decrease correlates with circulating testosterone $(T)$ concentrations. VCRs contain androgen receptors and $\mathrm{T}$ plays an important role in neural plasticity and in the control of singing behavior. In behaviorally dimorphic species, VCRs are larger in males than females and change seasonally also in females, but the dependency of these changes on circulating $T$ levels in females has not been established. In free-living adult dark-eyed juncos (Junco hyemalis), a species in which females do not normally sing, the sizes of three VCRs (high vocal center, robust nucleus of the
\end{abstract}

archistriatum, and Area $\mathrm{X}$ ) were larger in males than females and decreased between summer and fall in both sexes. In males, this decrease was associated with changes in circulating $T$ concentrations. Females, however, had on average undetectable $T$ levels throughout the breeding season. Seasonal changes in VCR volumes in adult females may depend on very low (below detection limit) circulating $\mathbf{T}$ concentrations, on nonandrogenic plasma steroids, on androgen (or androgen metabolites) produced in brain tissues, and/or on nonsteroidal factors such as photoperiod or social interactions with conspecific birds. () 2000 John Wiley \& Sons, Inc. J Neurobiol 42: 202-211, 2000

Keywords: junco; androgen; HVc; sexual dimorphism; plasticity
In oscine birds, song is a learned behavior controlled by a complex set of interconnected brain regions [vocal control regions (VCRs)] collectively called the song system. This system has traditionally been divided into anterior forebrain and caudal pathways. The anterior forebrain pathway is critical for song learning (Sohrabji et al., 1990; Bottjer and Johnson,

* Present address: Laboratory of Research in Psychiatry, Department of Psychiatry \#1007, Tufts University/NEMC, 750 Washington St., Boston, MA 02111

Correspondence to: P. Deviche at the Department of Biology, Arizona State University, Tempe, AZ 85287-1501

Contract grant sponsor: National Institute on Deafness and Other Communications Disorders; contract grant number: K01 DC00144 2317

Contract grant sponsor: NSF; contract grant number: IBN-96-

(C) 2000 John Wiley \& Sons, Inc. CCC 0022-3034/00/020202-10
1997; Doupe and Solis, 1997) and includes projections from the telencephalic high vocal center $(\mathrm{HVc})$ to Area $\mathrm{X}$ of the parolfactory lobe, which projects to the magnocellular nucleus of the anterior neostriatum (MAN) via the dorsolateral nucleus of the medial anterior thalamus (DLM), and eventually to the robust nucleus of the archistriatum (RA) (Nottebohm et al., 1976, 1982). The caudal pathway is critical for song production (Simpson and Vicario, 1990; Vicario and Simpson, 1995) and includes projections from HVc directly to RA (Kelley and Nottebohm, 1979). RA projects to the tracheosyringeal portion of the hypoglossal nucleus (nXII) (for review, see Wild, 1997), the source of axons to the syrinx or sound-producing organ.

The song system is sensitive to gonadal hormones during ontogeny (for review, see Arnold, 1992; Ar- 
nold et al., 1996; Bottjer and Arnold, 1997) and in adulthood (Rasika et al., 1994). In adult males, VCR volumes are larger during the breeding season, when song is expressed at a high rate and stereotyped, than after this season, when song is expressed at a low rate and/or is structurally less stable (Kirn et al., 1989; Gulledge and Deviche, 1997; Smith et al., 1997b,c; Brenowitz et al., 1998). Generally, plasma testosterone $(\mathrm{T})$ concentrations are also higher during than outside the breeding season (Wingfield and Farner, 1978a,b; Smith et al., 1996, 1997a; Brenowitz et al., 1996, 1998; Gulledge and Deviche, 1997) and they correlate with aspects of song (Galeotti et al., 1997). $\mathrm{T}$ administration stimulates singing (Logan and Carlin, 1991; Hunt et al., 1997; Gulledge and Deviche, 1998) and androgen receptors are located in HVc, RA, and MAN, but not Area X (Sohrabji et al., 1989; Gahr, 1990; Balthazart et al., 1992; Smith et al., 1996). This steroid plays a major role in the mediation of seasonal changes in VCR sizes and neural attributes (Gulledge and Deviche, 1997; Smith et al., 1997a).

In many species, males do all or most of the singing and have larger VCRs than conspecific females (Nottebohm et al., 1976; Arai et al., 1989; Kirn et al., 1989; Bernard et al., 1993; Brenowitz et al., 1994). As is the case in males, adult female VCRs decrease in size between the breeding and the postbreeding season (Kirn et al., 1989). Testosterone administration to adult females can increase or induce singing (canary, Serinus canarius: Leonard, 1939; Nottebohm, 1980; DeVoogd and Nottebohm, 1981; DeVoogd et al., 1985; Brown and Bottjer, 1993; white-crowned sparrow, Zonotrichia leucophrys: Kern and King, 1972; budgerigar, Melopsittacus undulatus: Nespor et al., 1996). This treatment to females also increases VCR sizes and induces HVc neural plasticity (Nottebohm, 1980; DeVoogd and Nottebohm, 1981; Goldman and Nottebohm, 1983; Brenowitz and Arnold, 1990; Brown and Bottjer, 1993; Gahr and Garcia-Segura, 1996), an effect that may be mediated by brain-derived neurotrophic factor (Rasika et al., 1999).

Whereas females of behaviorally dimorphic species can exhibit male-like behavioral and neuroanatomical changes when challenged with artificially elevated plasma $\mathrm{T}$ concentrations, the role of endogenous $\mathrm{T}$ in the control of VCR plasticity of these females is unclear. Studies examining effects of $\mathrm{T}$ administration on female VCR sizes or song expression either did not measure resulting circulating levels of the steroid (Gahr and Garcia-Segura, 1996; Nespor et al., 1996; Vallet et al., 1996) or reported levels similar to those measured in breeding males
(Luine et al., 1980; Nottebohm, 1980; DeVoogd and Nottebohm, 1981). During the reproductive period, peak plasma $\mathrm{T}$ concentrations of adult females belonging to sexually dimorphic species are, however, two to 10 times lower than those of conspecific males (white-crowned sparrow: Wingfield and Farner, 1978b; song sparrow, Melospiza melodia: Wingfield, 1984; pied flycatcher, Ficedula hypoleuca: Silverin and Wingfield, 1982; Bengalese finch, Lonchura striata: Seiler et al., 1992). Furthermore, endogenous T concentrations in these females are normally insufficient to induce male-typical song.

To investigate the potential role of endogenous $\mathrm{T}$ levels in the control of VCR plasticity in adult females, we measured circulating concentrations of this steroid and VCR sizes in adult breeding and postbreeding adult female dark-eyed juncos (Junco hyemalis), a species in which females do not (or rarely) sing, and we compared values with those obtained in males. We found that the sizes of several VCRs are sexually dimorphic and decrease between summer and fall in both sexes. T levels in males also decreased between summer and fall, but in most females they were undetectable throughout the breeding period and they did not change seasonally. Thus, very low (i.e., below detection limit) plasma $\mathrm{T}$ levels are sufficient to mediate seasonal changes of female VCR volumes and/or these changes depend on factor(s) other than circulating concentrations of this steroid.

\section{MATERIALS AND METHODS}

\section{Animal Collection and Brain Processing}

Dark-eyed juncos from interior Alaska return to their breeding areas at the end of April to early May. Males arrive, on average, earlier than females, and most breeding activities (pair formation, courtship, nest construction, egg laying, incubation, and raising of young) take place between midMay and early July. Males sing at a high rate between arrival and the end of June. In July, singing declines and the reproductive system rapidly involutes as birds become photorefractory (Deviche, 1995).

We collected birds around Fairbanks, Alaska $\left(65^{\circ} \mathrm{N}\right.$, $147^{\circ} \mathrm{W}$ ) using Japanese mist nets and seed-baited Potter traps during [breeding: May 15 to the end of June; males (M): $n=12$; females (F): $n=9$ ] and after (postbreeding: September; M: $n=5 ; \mathrm{F}: n=9)$ the reproductive season in $1994(n=13), 1996(n=7)$, and $1997(n=15)$. In the laboratory, we anesthetized juncos with an intramuscular injection of ketamine/xylazine solution followed with methoxy-fluorane (Metofane; Pitman-Moore, Mundelein, IL) inhalation and we perfused them with $4 \%$ paraformaldehyde as described elsewhere (Gulledge and Deviche, 1998). Brains were postfixed in situ overnight, dissected from 
skulls, and transferred to $0.1 \mathrm{M}$ phosphate buffer solution containing $0.1 \%$ sodium azide at $4^{\circ} \mathrm{C}$ (1-2 days) followed with $30 \%$ sucrose in the same buffer solution at $4{ }^{\circ} \mathrm{C}(10$ days). We weighed brains to the nearest milligram, coated them with embedding matrix (M-1; Lipshaw, Pittsburgh, PA) to prevent dehydration, froze them in powdered dry ice, and stored them at $-70^{\circ} \mathrm{C}$ until further processing. We cryostat-sectioned brains coronally $(50 \mu \mathrm{m})$ at $-15^{\circ} \mathrm{C}$ and collected alternate sections on gelatin-coated slides. Sections were desiccated overnight at room temperature and stained for Nissl substance with thionin.

\section{VCR Volume Measurement}

We measured the volumes of HVc, RA, Area X, (lateral plus medial) MAN, and a control brain region not involved in vocal behavior [nucleus rotundus (Rt)] of all birds, as described by Gulledge and Deviche (1998). Briefly, we identified regions on stained sections using the canary stereotaxic atlas (Stokes et al., 1974; Arnold et al., 1976) and measured these regions by computer-assisted morphometry. We calculated region volumes on each section by multiplying region cross-sectional area by section thickness. For each region, we then added individual section volumes in a brain, doubled the obtained values, and summed volumes for the left and right brain hemispheres of each bird. We also measured maximum telencephalon (Tel) width (left plus right hemispheres) at the rostro-caudal level of the anterior commissure as a control for overall brain size (Gulledge and Deviche, 1998).

Brains used for this study were collected during 3 different years, and care was taken to standardize all steps of tissue processing. Furthermore, the same person made all volume measurements. It is, however, possible that slight year-to-year differences in processing produced differential shrinkage of tissues during perfusions and soaking in sucrose solution. To account for this possibility, we examined the contribution of overall brain size (as estimated by Tel width) to individual differences in each VCR and Rt volumes with data collected over the study period combined. For this, we performed multiple linear regressions with sex, breeding condition (breeding or postbreeding), and Tel width as independent variables, and the volumes of each VCR (or Rt) as a dependent variable. Differences in brain size contributed significantly to individual differences in HVc $(p=.044)$, RA $(p=.004)$, Area X $(p=.004)$, and Rt $(p=.009)$, but not MAN $(p=.8)$ volumes. We eliminated this contribution by normalizing volumes of each VCR (except MAN) and of Rt with respect to individual differences in Tel widths using multiple regression equation coefficient values. Normalized volumes were, therefore, independent of brain size ( $p$ s all >.9). These volumes were used for all statistical analyses and data presentation. We analyzed the influence of sex and season (and the interaction between these variables) on Tel width and on normalized brain region volumes by two-way analysis of variance (ANOVA). All data sets met ANOVA assumptions of normality and equal variance. When appropriate, ANOVAs were followed with Student-Newman-Keuls multiple comparison tests. Significance level was in all cases set at $\alpha$ $=.05$ and all results are presented as means \pm standard deviations.

\section{Plasma Testosterone Concentrations}

A blood sample (approximately $200 \mu \mathrm{L}$ ) was collected into heparinized microhematocrit tubes from a brachial vein of birds caught between the end of April and September, 1996-1998. Blood samples were obtained within minutes of capture. Within hours of collection, they were centrifuged $\left(3000 \mathrm{rpm}, 10 \mathrm{~min}, 4^{\circ} \mathrm{C}\right)$ and plasma was collected and stored at $-20^{\circ} \mathrm{C}$ until assayed. We measured plasma $\mathrm{T}$ concentrations using a direct solid-phase radioimmunoassay (Diagnostic Products Corp., Los Angeles, CA) as described by Gulledge and Deviche (1998). The antibody used for the assay has low $(<5 \%)$ cross reactivity with estradiol, progesterone, and $5 \alpha$-dihydrotestosterone. All samples were assayed in duplicate using $25-50 \mu \mathrm{L}$ of plasma/assay tube. The minimum detectable amount of hormone was 5-10 pg/assay tube (corresponding to $0.1-0.4 \mathrm{ng} / \mathrm{mL}$ plasma) depending on the plasma volume used, and the intraassay coefficient of variation was within the range of that previously reported (Gulledge and Deviche, 1998).

To determine seasonal and age-related changes in plasma $\mathrm{T}$ concentrations, we applied two-way ANOVA to data collected only between May 15 and the end of June and in September (corresponding to when brains were obtained). Sample sizes were $n=102$ (summer males), $n=22$ (fall males), $n=37$ (summer females), and $n=7$ (fall females). Data were not normally distributed and were therefore ranked before analysis (Conover and Iman, 1981). We analyzed seasonal changes in female plasma $\mathrm{T}$ levels in more detail by dividing all samples according to collection dates (end of April to end of May: $n=15$; June: $n=24$; July: $n$ =16; August: $n=3$; September: $n=7$ ) and comparing average monthly $\mathrm{T}$ levels by one-way Kruskal-Wallis ANOVA on ranks. Data are presented as medians \pm halfinterquartile intervals (Nicholson et al., 1997).

\section{RESULTS}

\section{Brain Region Volumes}

The sizes of all VCRs were sexually dimorphic and changed seasonally (Figs. 1 and 2, and Table 1). On average, male to female volume ratios were 4.46 (HVc), 3.58 (RA), 3.53 (Area X), and 2.70 (MAN). In males, normalized HVc, RA, and area $\mathrm{X}$ sizes decreased by $31.93 \%\left(0.32 \pm 0.07 \mathrm{~mm}^{3}\right), 19.05 \%(0.07$ $\left.\pm 0.04 \mathrm{~mm}^{3}\right)$, and $23.4 \%\left(0.34 \pm 0.26 \mathrm{~mm}^{3}\right)$, respectively, between summer and fall. Corresponding normalized volume decreases in females were $44.23 \%$ $\left(0.12 \pm 0.09 \mathrm{~mm}^{3}\right), 30.36 \%\left(0.03 \pm 0.02 \mathrm{~mm}^{3}\right)$, and $43.64 \%\left(0.22 \pm 0.12 \mathrm{~mm}^{3}\right)$. 


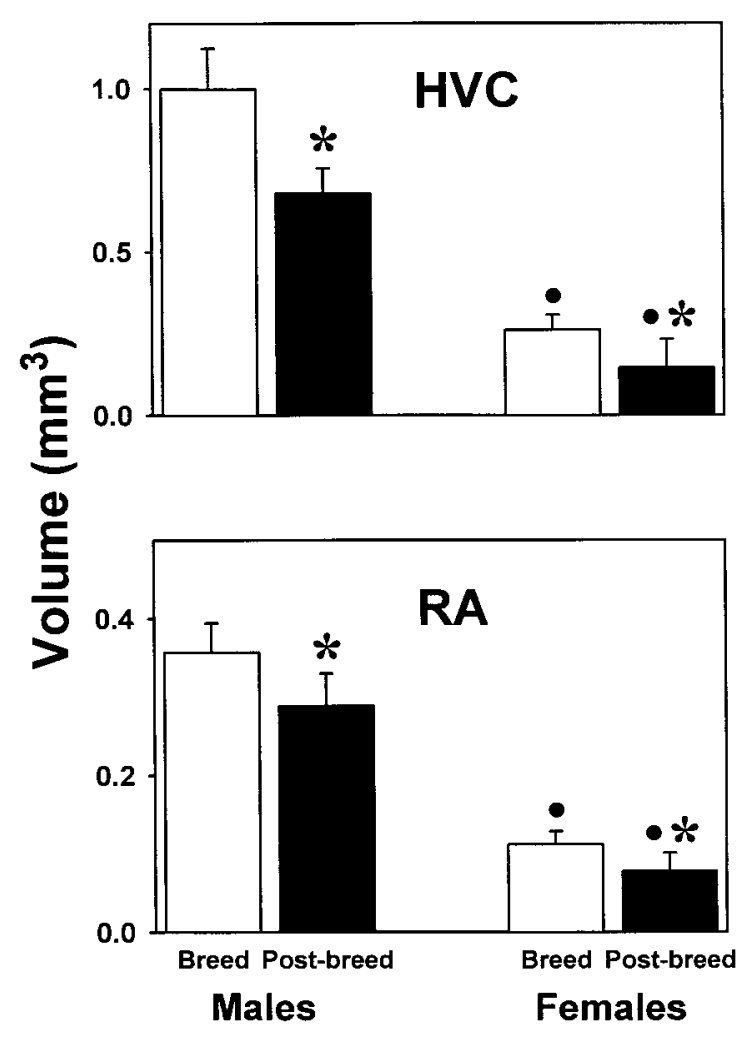

Figure 1 Normalized volumes (means + standard deviations) of the High Vocal Center $(\mathrm{HVc})$ and $n$. robustus of the archistriatum (RA) of adult breeding and postbreeding male $(n=12$ and 5) and female ( $n=9$ and 9$)$ dark-eyed juncos (Junco hyemalis) obtained from a free-living population in interior Alaska $\left(65^{\circ} \mathrm{N}, 147^{\circ} \mathrm{W}\right)$. For each brain region, asterisk indicates a seasonal difference within a same sex, whereas bullet indicates a difference between males and females within a same season (Student-Newman-Keuls multiple comparison test, $p<.05$ ).

There was no interaction between sex and season for RA or Area X, indicating that seasonal normalized volume changes in these regions were of similar magnitudes in both sexes. A Sex $\times$ Season interaction was identified for HVc. The normalized volumes of this region decreased significantly between summer and fall in both sexes, but more so in males than females (comparison of differences between group mean summer and individual fall volumes: Student $t$ test: $t_{12}$ $=4.353, p<.001)$. HVc sizes, however, decreased by the same relative proportion (percentage decrease between summer and fall for each sex) in both sexes between the two seasons (Student $t$ test: $p>.4$ ). MAN sizes increased between summer and fall in males, but not females.

Tel width increased by $3.6 \%$ between summer $(13.04 \pm 0.44 \mathrm{~mm})$ and fall $(13.51 \pm 0.29 \mathrm{~mm})$, and there was a nearly significant Sex $\times$ Season interac- tion (Fig. 3 and Table 1). Pairwise comparisons revealed that the seasonal increase in width occurred in females only. The volume of a control brain region (Rt) was not sexually dimorphic and did not vary seasonally. Maximum Tel width was positively correlated to brain weight (Pearson product moment coefficient: $r=.643, n=35: p<.001)$ and Rt volume (id.: $r=.478, p=.004$ ).

\section{Plasma Testosterone Concentrations}

Testosterone was detected in samples collected from 7 of 65 females and exceeded $1 \mathrm{ng} / \mathrm{mL}$ in one female (May: $2.18 \mathrm{ng} / \mathrm{mL}$ ). Average hormone concentrations in females sampled in April to the end of May, June, July, August, and September all were below the assay sensitivity limit and did not change seasonally (Kruskal-Wallis one-way ANOVA on ranks: $p$ $=.14)$.

Analysis of plasma T levels in samples collected May 15 to the end of June and in September revealed

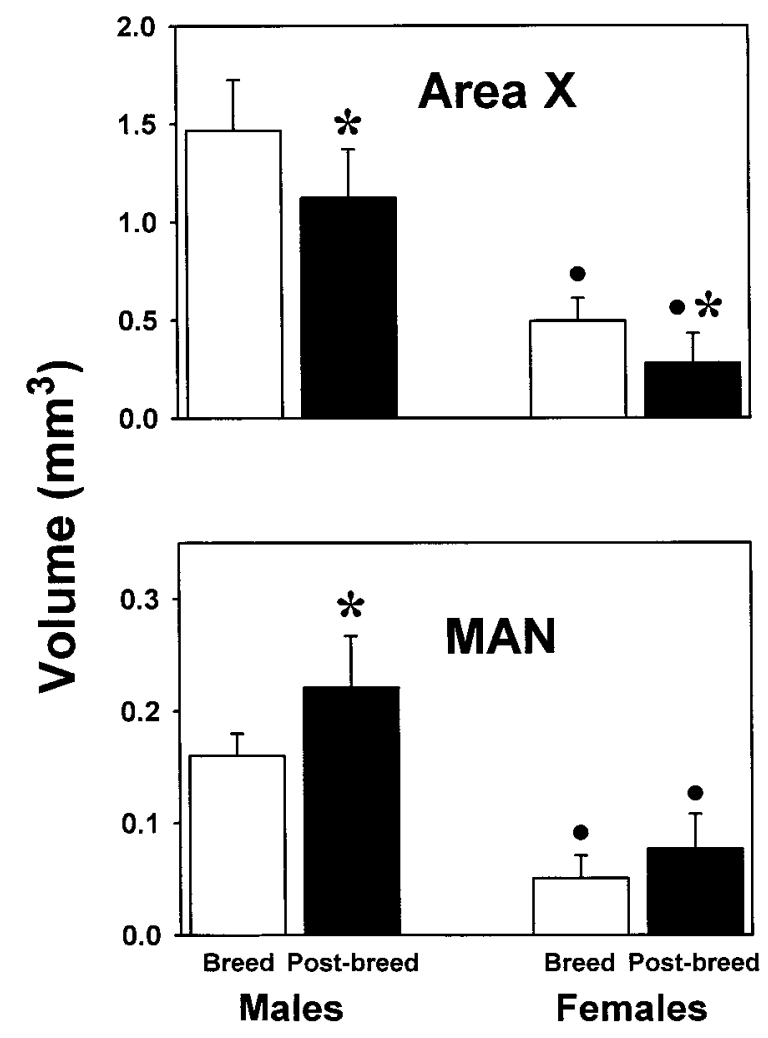

Figure 2 Normalized volumes (means + standard deviations) of Area $\mathrm{X}$ and absolute volumes (id.) of the magnocellular $\mathrm{n}$. of the anterior neostriatum (MAN) of adult breeding and postbreeding male $(n=12$ and 5) and female $(n=9$ and 9) dark-eyed juncos (Junco hyemalis). See Figure 1 for additional information. 
Table 1 Results of Two-Way Analyses of Variance (ANOVA) Comparing Normalized Volumes of Three Vocal System (HVc, RA, and Area X) and One Control (n. rotundus) Regions as Well as Absolute Volumes of MAN and Telencephalon Width of Adult Breeding and Postbreeding Male $(n=12$ and 5) and Female $(n=9$ and 9$)$ Dark-Eyed Juncos (Junco hyemalis)

\begin{tabular}{|c|c|c|c|}
\hline & Sex & Season & Interaction \\
\hline $\mathrm{HVC}\left(\mathrm{mm}^{3}\right)$ & $\begin{array}{c}F_{1,34}=362.83 \\
p<.001\end{array}$ & $\begin{array}{c}F_{1,34}=42.163 \\
p<.001\end{array}$ & $\begin{array}{c}F_{1,34}=9.333 \\
p=.005\end{array}$ \\
\hline $\mathrm{RA}\left(\mathrm{mm}^{3}\right)$ & $\begin{array}{c}F_{1,33}=424.36 \\
p<.001\end{array}$ & $\begin{array}{c}F_{1,33}=21.489 \\
p<.001\end{array}$ & $\underset{\mathrm{NS}}{F_{1,33}}=2.398$ \\
\hline Area $X\left(\mathrm{~mm}^{3}\right)$ & $\begin{array}{c}F_{1,32}=143.27 \\
p<.001\end{array}$ & $\begin{array}{c}F_{1,33}=13.589 \\
p<.001\end{array}$ & $\underset{\mathrm{NS}}{F_{1,33}}=0.699$ \\
\hline MAN $\left(\mathrm{mm}^{3}\right)$ & $\begin{array}{c}F_{1,30}=139.49 \\
p<.001\end{array}$ & $\begin{array}{c}F_{1,30}=16.529 \\
p<.001\end{array}$ & $\underset{\text { NS }}{F_{1,30}}=2.583$ \\
\hline Telencephalon width (mm) & $\underset{\mathrm{NS}}{F_{1,34}}=2.955$ & $\begin{array}{c}F_{1,34}=16.15 \\
p<.001\end{array}$ & $\begin{array}{c}F_{1,34}=3.902 \\
p=.057\end{array}$ \\
\hline n. rotundus $\left(\mathrm{mm}^{3}\right)$ & $\underset{\mathrm{NS}}{F_{1,34}}=0.153$ & $\underset{\text { NS }}{F_{1,34}}=0.982$ & $\underset{\text { NS }}{F_{1,34}}=0.017$ \\
\hline
\end{tabular}

For each parameter under study, the table indicates observed $F$ values (with associated degrees of freedom) and corresponding probabilities. NS $=$ nonsignificant $(p>.05)$.

a sex $\left(F_{1,167}=53.911, p<.001\right)$ and a season $\left(F_{1,167}\right.$ $=26.829, p<.001)$ difference as well as a Sex $\times$ Season interaction $\left(F_{1,167}=17.989, p<.001\right)$
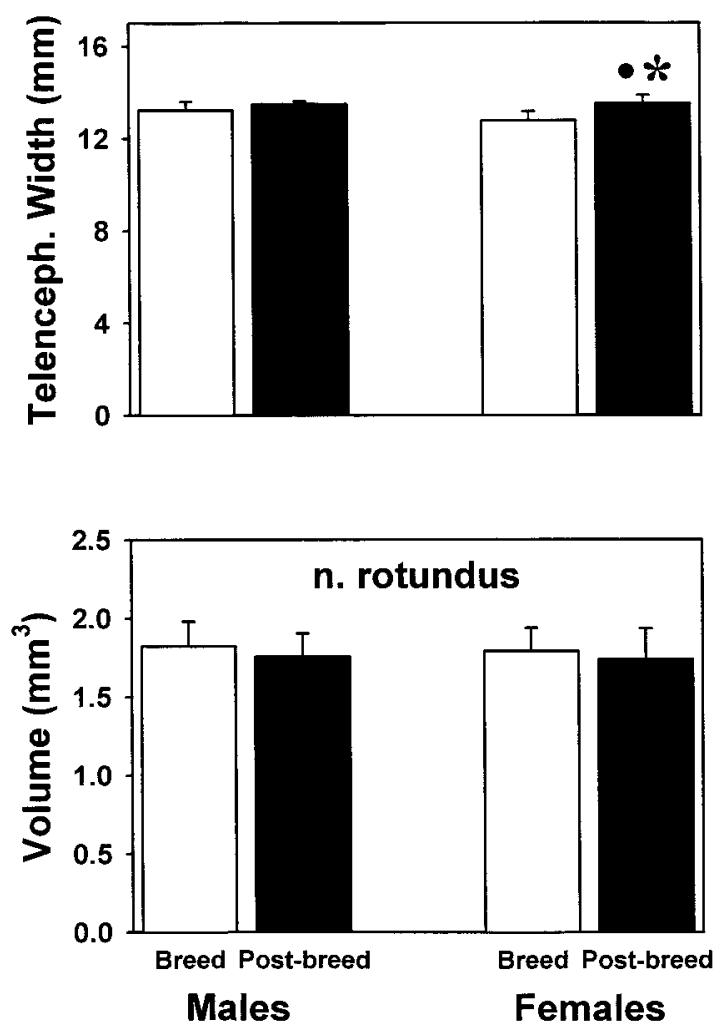

Figure 3 Telencephalon widths (means + standard deviations) and volumes of the n. rotundus (id.) of adult breeding and postbreeding male $(n=12$ and 5) and female $(n=9$ and 9) dark-eyed juncos (Junco hyemalis). See Figure 1 for additional information.
(Fig. 4). During the May 15 to the end of June period, average plasma $\mathrm{T}$ concentrations were $3.36 \mathrm{ng} / \mathrm{mL}$ in males and below the assay detection limit in females $(p<.05)$. Average $\mathrm{T}$ levels were below the assay sensitivity limit in both sexes in September.

\section{DISCUSSION}

\section{Seasonal Changes in Vocal Control Region Sizes: Males versus Females}

This study demonstrates that the sizes of three VCRs (HVc, RA, and Area X) of a free-living oscine de-

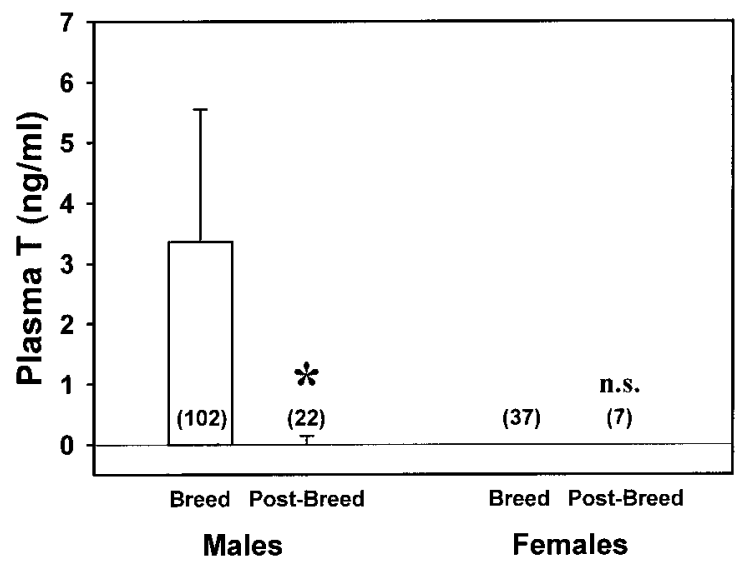

Figure 4 Plasma testosterone $(\mathrm{T})$ concentrations (medians + half-interquartile intervals) of breeding and postbreeding adult male and female dark-eyed juncos (Junco hyemalis). Numbers in parentheses refer to sample sizes. See Figure 1 for additional information. $* p<.05$; (n.s. $>.05$ ), comparison with corresponding group of breeding birds (StudentNewman-Keuls multiple comparison test). 
crease in both sexes at the end of the breeding period. This decrease was specific to song regions, as the volume of a region that is not involved in vocal behavior production or perception (Rt) did not vary between summer and fall. Furthermore, seasonal volume decreases were independent of overall brain size, as measured by telencephalon width. Our data are consistent with another study that also demonstrated seasonal, region-specific changes in VCR sizes in adult females (red-winged blackbird, Agelaius phoeniceus: Kirn et al., 1989). The VCRs of adult female juncos were on average 2.70 (MAN) to 4.46 (HVc) times smaller than those of males. These ratios resemble those reported in other species in which males either do all or most of the singing or have a larger vocal repertoire than females (Nottebohm, 1980; Canady et al., 1984; Arai et al., 1989; Kirn et al., 1989; Bernard et al., 1993). The volume of MAN increased between summer and fall in males. The significance of this result is unclear because in a previous study, male junco MAN volumes did not change seasonally and did not differ between castrated birds that did or did not receive exogenous $\mathrm{T}$ (Gulledge and Deviche, 1997).

Seasonal changes in HVc, Area X, and probably RA volumes in male juncos are partly regulated by circulating $\mathrm{T}$ concentrations. These volumes decrease between summer and fall in parallel with plasma $\mathrm{T}$ levels. Furthermore, castration of males in breeding condition caused a reduction in $\mathrm{HVc}$ and Area X volumes that was prevented by $\mathrm{T}$ replacement at physiological doses (Gulledge and Deviche, 1997). Other investigations likewise identified an important role for $\mathrm{T}$ in the control of adult male VCR sizes (Brown and Bottjer, 1993; Bernard and Ball, 1997; Smith et al., 1997a). In contrast to males, female juncos had, on average, undetectable plasma $\mathrm{T}$ levels throughout the breeding season. Seasonal changes in VCR volumes in females were therefore not associated with measurable alterations of their circulating androgen concentrations. This result may be interpreted in several ways.

\section{Neuroendocrine Control of Region Volume Changes in Adult Females}

Steroid Hormones. One possibility is that female juncos had elevated plasma $\mathrm{T}$ levels before arrival on breeding grounds and hormone levels had decreased by the time birds reached the study area. This hypothesis is unlikely because in other migratory female songbirds maximum plasma $\mathrm{T}$ concentrations occurred during spring migration and shortly after arrival on breeding grounds and pairing (Wingfield and
Farner, 1978a,b) or during incubation (Silverin and Wingfield, 1982). In the present study, females were sampled during these phases of their annual cycle and the hormone assay sensitivity was comparable to that reported in other investigations. Alternately, it is possible that plasma $\mathrm{T}$ concentrations in female juncos vary seasonally and are responsible for seasonal changes in VCR volumes, but peak hormone levels do not reach $0.1 \mathrm{ng} / \mathrm{mL}$ plasma (assay detection limit). This possibility cannot be excluded at the present time, although it should be pointed out that no experimental evidence supports the idea that such low circulating $\mathrm{T}$ concentrations influence VCR sizes or functions in any adult oscine.

Seasonal VCR plasticity in adult females may depend on an influence of peripherally and/or centrally produced estradiol and/or a combined action of androgens and estrogens. Circulating estradiol levels in females are elevated during the breeding season (Wingfield and Farner, 1978a,b; Wingfield, 1984). In some species, HVc as well as an area surrounding RA contain estrogen receptors in both sexes (Gahr, 1987, 1990; Brenowitz and Arnold, 1989; Gahr et al., 1993; Brenowitz et al., 1996). In addition, HVc volume in canaries decreases after ovariectomy (Nottebohm, 1980) and estradiol (E) exerts multiple neurotrophic (RA dendrite growth: DeVoogd and Nottebohm, 1981; incorporation of new neurons into HVc: Hidalgo et al., 1995; Goldman, 1998) and neurochemical (catecholamine turnover: Barclay and Harding, 1990) effects on VCRs. Some effects of T on the adult song system may therefore result from aromatization of this steroid into E taking place peripherally and/or centrally (Schlinger and Arnold, 1991; Shen et al., 1994; Saldanha and Schlinger, 1997; dark-eyed junco: Plumari et al., 1998). It should be pointed out that in species exhibiting adult neural plasticity, the influence of $\mathrm{T}$ administration is only partially replicated by $\mathrm{E}$ treatment. Administration of estradiol to adults does not induce singing (DeVoogd and Nottebohm, 1981; Harding et al., 1988; but see Walters et al., 1991) and has so far not been shown to increase VCR sizes. These observations suggest that androgens induce behavioral and neural changes partly following aromatization, but also by direct activation of androgen receptor-mediated processes. Zebra finch (Taeniopygia guttata) brain tissues contain the enzyme $3 \beta$-hydroxysteroid dehydrogenase that converts $\left[{ }^{3} \mathrm{H}\right]$ pregnenolone into $\left[{ }^{3} \mathrm{H}\right]$ progesterone and $\left[{ }^{3} \mathrm{H}\right]$ dehydroepiandrosterone into the androgen $\left[{ }^{3} \mathrm{H}\right]$ androstenedione (Vanson et al., 1996). Accordingly, it is conceivable that brain tissues of intact birds synthesize androgens de novo 
(also see Schlinger, 1997) and that E-mediated effects on VCRs occur in the absence of circulating androgens. Following this hypothesis, seasonal changes in adult songbird VCR sizes may involve complementary actions of peripherally and/or centrally produced estrogens and of centrally synthesized androgens.

Photoperiod. Several investigations have demonstrated a gonadal hormone-independent stimulating influence of long photoperiod on VCR sizes (Bernard and Ball, 1995, 1997; Bernard et al., 1997; Smith et al., 1997a). Exposure of photorefractory male juncos to long photoperiod increased the sizes of HVc and Area X compared to birds held on short photoperiod, although circulating $\mathrm{T}$ was undetectable in all birds (Gulledge and Deviche, 1998). Transfer of male canaries from spring- to fall-like condition markedly increased $\mathrm{HVc}$ cell death rate and tended to reduce this region's volume without consistently affecting plasma $\mathrm{T}$ concentrations (Kirn and Schwabl, 1997). Photoperiod in interior Alaska decreases from approximately $23 \mathrm{~h}$ in June to $12 \mathrm{~h}$ in September. This large decrease may promote a reduction of female junco VCR volumes in the absence of detectable circulating $\mathrm{T}$.

Social Factors. Female VCR sizes may finally decrease between summer and fall owing to an influence of social factors, such as changes in song rates of conspecific males. Several studies demonstrate that females are sensitive to aspects of conspecific male songs. For example, female great tits (Parus major) and song sparrows can identify their mate based on individual song features (Lind et al., 1996; O'Loghlen and Beecher, 1997), and female pied flycatchers prefer males that produce longer songs (Lampe and Saetre, 1995). In females, HVc and MAN play an important role in song perception (Brenowitz, 1991; Hamilton et al., 1997) and presentation of conspecific song playbacks stimulates immediate-early gene expression in auditory brain areas of female canaries and zebra finches (Mello and Ribeiro, 1998). A recent study found that VCR sizes of adult male whitecrowned sparrows are influenced by social factors (Tramontin et al., 1999). Specifically, photostimulated males paired with a sexually receptive female had larger $\mathrm{HVc}$ and RA than males not exposed to females, although both groups of males had similar plasma $\mathrm{T}$ levels. Male juncos sing at a high rate during the breeding period, but not (or rarely) in the fall (personal observations), and maintenance of VCR sizes during the breeding season in females may likewise depend on auditory or other social stimulation provided by conspecific males. Additional research is warranted to evaluate this possibility and to elucidate the neurophysiological mechanisms by which acoustic information may be transduced into neural plasticity.

\section{Functional Implications of Seasonal Changes in Region Volumes in Adult Females}

The function of seasonal changes in song-related region volumes and attributes remains a matter of debate. Early studies suggested that these changes relate to seasonal song learning and forgetting (Nottebohm, 1981). Subsequent investigations, however, identified seasonal VCR size modifications in species that do not change their songs as adults (Arai et al., 1989; Brenowitz, 1991; Brenowitz et al., 1991, 1996; Smith et al., 1995). More recently, authors found correlations between seasonal changes in VCR sizes and aspects of song stereotypy (Smith et al., 1995, 1997c; Brenowitz et al., 1998), suggesting that seasonal plasticity of the adult male song system may regulate vocal behavioral stereotypy rather than new song learning. In the present study, the HVc, RA, and Area $\mathrm{X}$ underwent similar seasonal volume changes in both sexes, although female juncos do not normally produce male-typical songs. Seasonal changes in female VCR sizes may either control changes in the stereotypy of learned vocalizations other than male-typical song and/or modulate seasonal modifications in the perception of species-specific vocal behavior. The latter possibility is supported by the fact that lesions of HVc (female canary: Brenowitz, 1991; Del Negro et al., 1998) or of the caudal hyperstriatum ventrale, an auditory area that projects to HVc (female zebra finch: MacDougall-Shackleton et al., 1998), have detrimental effects on the discrimination of conspecific and of species-specific songs. Further research is needed to elucidate the functions of seasonal changes in the size of this and other song-related regions, to identify the neural mechanisms that control the perceptual abilities of nonsinging female birds, and to determine whether and how these abilities vary between the breeding and the nonbreeding season and as a function of the hormonal environment.

Thanks are due to John Kirn for comments on a draft of the manuscript, and to Cynthia Simons, Amy MacCauley, and Daniel Eckman for assistance with bird capture. This work was partly supported by National Institute on Deafness and Other Communications Disorders Grant K01 DC00144 (PD) and by National Science Foundation Dissertation Improvement Grant IBN-96-23171 (PD, CG). 


\section{REFERENCES}

Arai O, Taniguchi I, Saito N. 1989. Correlations between the size of song control nuclei and plumage color change in orange Bishop birds. Neurosci Lett 98:144-148.

Arnold AP. 1992. Developmental plasticity in neural circuits controlling bird song: sexual differentiation and the neural basis of learning. J Neurobiol 23:1506-1528.

Arnold AP, Nottebohm F, Pfaff DW. 1976. Hormone concentrating cells in vocal control and other areas of the brain of the Zebra Finch (Poephila guttata). J Comp Neurol 165:487-512.

Arnold AP, Wade J, Grisham W, Jacobs EC, Campagnoni AT. 1996. Sexual differentiation of the brain in songbirds. Dev Neurosci 18:124-136.

Balthazart J, Foidart A, Wilson EM, Ball GF. 1992. Immunocytochemical localization of androgen receptors in the male songbird and quail brain. J Comp Neurol 317:407420.

Barclay SR, Harding CF. 1990. Differential modulation of monoamine levels and turnover rates by estrogen and/or estrogen in hypothalamic and vocal control nuclei of male zebra finches. Brain Res 523:251-262.

Bernard DJ, Ball GF. 1995. Two histological markers reveal a similar photoperiodic difference in the volume of the high vocal center in male European Starlings. J Comp Neurol 360:726-734.

Bernard DJ, Ball GF. 1997. Photoperiodic condition modulates the effects of testosterone on song control nuclei volumes in male European Starlings. Gen Comp Endocrinol 105:276-283.

Bernard DJ, Casto JM, Ball GF. 1993. Sexual dimorphism in the volume of song control nuclei in the European Starlings: assessment by a Nissl stain and autoradiography for muscarinic cholinergic receptors. J Comp Neurol 334:559-570.

Bernard DJ, Wilson FE, Ball GF. 1997. Testis-dependent and -independent effects of photoperiod on volumes of song control nuclei in American tree sparrows (Spizella arborea). Brain Res 760:163-169.

Bottjer SW, Arnold AP. 1997. Developmental plasticity in neural circuits for a learned behavior. Annu Rev Neurosci 20:459-481.

Bottjer SW, Johnson F. 1997. Circuits, hormones, and learning: vocal behavior in songbirds. J Neurobiol 33:602618.

Brenowitz EA. 1991. Altered perception of species-specific song by female birds after lesions of a forebrain nucleus. Science 251:303-305.

Brenowitz EA, Arnold AP. 1989. Accumulation of estrogen in a vocal control brain region of a duetting song bird. Brain Res 480:119-125.

Brenowitz EA, Arnold AP. 1990. The effects of systemic androgen treatment on androgen accumulation in song control regions of the adult female canary brain. J Neurobiol 21:837-843.

Brenowitz EA, Arnold AP, Loesche P. 1996. Steroid accumulation in song nuclei of a sexually dimorphic duetting bird, the Rufous and White Wren. J Neurobiol 31:235244.

Brenowitz EA, Nalls B, Wingfield JC, Kroodsma DE. 1991. Seasonal changes in avian song nuclei without seasonal changes in song repertoire. J Neurosci 11:1367-1374.

Brenowitz EA, Nalls B, Kroodsma DE, Horning C. 1994. Female Marsh Wrens do not provide evidence of anatomical specializations of song nuclei for perception of male song. J Neurobiol 25:197-208.

Brenowitz EA, Baptista LF, Lent K, Wingfield JC. 1998. Seasonal plasticity of the song control system in wild Nuttall's white-crowned sparrows. J Neurobiol 34:6982.

Brown SD, Bottjer SW. 1993. Testosterone-induced changes in adult canary brain are reversible. J Neurobiol 24:627-640.

Canady R, Kroodsma DE, Nottebohm F. 1984. Population differences in complexity of a learned skill are correlated with the brain space involved. Proc Natl Acad Sci USA 81:6232-6234.

Conover WJ, Iman RL. 1981. Rank-transformations as a bridge between parametric and nonparametric statistics. Am Stat 35:124-129.

Del Negro C, Gahr M, Leboucher G, Kreutzer M. 1998. The selectivity of sexual responses to song displays: effects of partial chemical lesion of the HVC in female canaries. Behav Brain Res 96:151-159.

Deviche P. 1995. Androgen regulation of avian premigratory hyperphagia and fattening: from ecophysiology to neuroendocrinology. Am Zool 35:234-245.

DeVoogd TJ, Nottebohm F. 1981. Gonadal hormones induced dendritic growth in the adult avian brain. Science 214:202-204.

DeVoogd TJ, Nixdorf B, Nottebohm F. 1985. Synaptogenesis and changes in synaptic morphology related to acquisition of a new behavior. Brain Res 329:304-308.

Doupe AJ, Solis MM. 1997. Song- and order-selective neurons develop in the songbird anterior forebrain during vocal learning. J Neurobiol 33:694-709.

Gahr M. 1990. Localization of androgen receptors and estrogen receptors in the same cells of the songbird brain. Proc Natl Acad Sci USA 87:9445-9448.

Gahr M, Flugge G, Guttinger H-R. 1987. Immunocytochemical localization of estrogen-binding neurons in the songbird brain. Brain Res 402:173-177.

Gahr M, Garcia-Segura LM. 1996. Testosterone-dependent increase of gap-junctions in HVc neurons of adult female canaries. Brain Res 712:69-73.

Gahr M, Guttinger H-R, Kroodsma DE. 1993. Estrogen receptors in the avian brain: survey reveals general distribution and forebrain areas unique to songbirds. J Comp Neurol 327:112-122.

Galeotti P, Saino N, Sacchi R, Møller AP. 1997. Song correlates with social context, testosterone and body condition in male barn swallows. Anim Behav 53:687-700.

Goldman SA. 1998. Adult neurogenesis: from canaries to the clinic. J Neurobiol 36:267-286.

Goldman SA, Nottebohm F. 1983. Neuronal production, 
migration, and differentiation in a vocal control nucleus of the adult female canary brain. Proc Natl Acad Sci USA 80:2390-2394.

Gulledge CC, Deviche P. 1997. Androgen control of vocal control region volumes in a wild migratory songbird (Junco hyemalis) is region and possibly age dependent. J Neurobiol 32:391-402.

Gulledge CC, Deviche P. 1998. Photoperiod and testosterone independently affect vocal control region volumes in adolescent male songbirds. J Neurobiol 36:550-558.

Hamilton KS, King AP, Sengelaub DR, West MJ. 1997. A brain of her own: a neural correlate of song assessment in a female songbird. Neurobiol Learn Mem 68:325-332.

Harding CF, Walters MJ, Collado D, Sheridan K. 1988. Hormonal specificity and activation of social behavior in male Red-winged Blackbirds. Horm Behav 22:402-418.

Hidalgo A, Barami K, Goldman SA. 1995. Estrogens and non-estrogenic ovarian influences combine to promote the recruitment and decrease the turnover of new neurons in the adult female canary brain. J Neurobiol 27:470487.

Hunt KE, Hahn TP, Wingfield JC. 1997. Testosterone implants increase song but not aggression in male Lapland longspurs. Anim Behav 54:1177-1192.

Kelley DB, Nottebohm F. 1979. Projections of a telencephalic auditory nucleus_-Field L_in the canary. J Comp Neurol 183:455-470.

Kern MD, King JR. 1972. Testosterone-induced singing in female White-crowned Sparrows. Condor 74:204-209.

Kirn JR, Schwabl H. 1997. Photoperiod regulation of neuron death in the adult canary. J Neurobiol 33:223-231.

Kirn JR, Clower RP, Kroodsma DE, DeVoogd T. 1989. Song-related brain regions in the Red-winged Blackbird are affected by sex and season but not repertoire size. J Neurobiol 20:139-163.

Lampe HM, Saetre G-P. 1995. Female Pied Flycatchers prefer males with larger song repertoires. Proc R Soc Lond B 262:163-167.

Leonard SL. 1939. Induction of singing in female canaries by injections of male hormone. Proc Soc Exp Biol Med 41:229-230.

Lind H, Dabelsteen T, McGregor PK. 1996. Female Great Tits can identify mates by song. Anim Behav 52:667671.

Logan CA, Carlin CA. 1991. Testosterone stimulates reproductive behavior during autumn in Mockingbirds (Mimus polyglottos). Horm Behav 25:229-241.

Luine V, Nottebohm F, Harding CF, McEwen BS. 1980. Androgen affects cholinergic enzymes in syringeal motor neurons and nuclei. Brain Res 192:89-107.

MacDougall-Shackleton SA, Hulse SH, Ball GF. 1998. Neural bases of song preferences in female zebra finches (Taeniopygia guttata). Neuroreport 9:3047-3052.

Mello CV, Ribeiro S. 1998. ZENK protein regulation by song in the brain of songbirds. J Comp Neurol 393:426438.

Nespor AA, Lukazewicz MJ, Dooling RJ, Ball GF. 1996. Testosterone induction of male-like vocalizations in fe- male Budgerigars (Melopsittacus undulatus). Horm Behav 30:162-169.

Nicholson MC, Bowyer RT, Kie JG. 1997. Habitat selection and survival of Mule Deer: tradeoffs associated with migration. J Mammol 78:483-504.

Nottebohm F. 1980. Testosterone triggers growth of brain vocal control nuclei in adult female canaries. Brain Res 189:429-436.

Nottebohm F. 1981. A brain for all seasons: cyclical anatomical changes in song control nuclei of the canary brain. Science 214:1368-1370.

Nottebohm F, Arnold AP. 1996. Sexual dimorphism in vocal control areas of the songbird brain. Science 194: 211.

Nottebohm F, Stokes TM, Leonard CM. 1976. Central control of song in the canary, Serinus canarius. J Comp Neurol 165:457-486.

Nottebohm F, Kelley DB, Paton JA. 1982. Connections of vocal control nuclei in the canary telencephalon. J Comp Neurol 207:344-357.

O'Loghlen AL, Beecher MD. 1997. Sexual preferences for mate song types in female song sparrows. Anim Behav 53:835-841.

Plumari L, Deviche P, Harada N, Panzica GC. 1998. Effects of photoperiodic condition on the brain distribution of aromatase-immunoreactive cells in a male songbird (Junco hyemalis). Abstract of the annual meeting of the Society for Neuroscience, Los Angeles, CA.

Rasika S, Nottebohm F, Alvarez-Buylla A. 1994. Testosterone increases the recruitment and/or survival of new high vocal center neurons in adult female canaries. Proc Natl Acad Sci USA 91:7854-7858.

Rasika S, Alvarez-Buylla A, Nottebohm F. 1999. BDNF mediates the effects of testosterone on the survival of new neurons in an adult brain. Neuron 22:53-62.

Saldanha CJ, Schlinger BA. 1997. Estrogen synthesis and secretion in the Brown-Headed Cowbird (Molothrus ater). Gen Comp Endocrinol 105:390-401.

Schlinger BA. 1997. Sex steroids and their actions on the birdsong system. J Neurobiol 33:619-631.

Schlinger BA, Arnold AP. 1991. Brain is the major site of estrogen synthesis in a male songbird. Proc Natl Acad Sci USA 88:4191-4194.

Seiler HW, Gahr M, Goldsmith AR, Guttinger H-R. 1992. Prolactin and gonadal steroids during the reproductive cycle of the Bengalese Finch (Lonchura striata var. domestica, Estrildidae), a nonseasonal breeder with biparental care. Gen Comp Endocrinol 88:83-90.

Shen P, Campagnoni CW, Kampf K, Schlinger BA, Arnold AP, Campagnoni AT. 1994. Isolation and characterization of a Zebra Finch aromatase cDNA: in situ hybridization reveals high aromatase expression in brain. Mol Brain Res 24:227-237.

Silverin B, Wingfield JC. 1982. Patterns of breeding behaviour and plasma levels of hormones in a free-living population of Pied Flycatchers, Ficedula hypoleuca. J Zool Lond 198:117-129.

Simpson HB, Vicario DS. 1990. Brain pathways for learned 
and unlearned vocalizations differ in Zebra Finches. J Neurosci 10:1541-1556.

Smith GT, Brenowitz EA, Prins GS. 1996. Use of PG-21 immunocytochemistry to detect androgen receptors in the songbird brain. J Histochem Cytochem 44:1075-1080.

Smith GT, Brenowitz EA, Wingfield JC, Baptista LF. 1995. Seasonal changes in song nuclei and song behavior in Gambel's White-crowned Sparrows. J Neurobiol 28:114-125.

Smith GT, Brenowitz EA, Wingfield JC. 1997a. Roles of photoperiod and testosterone in seasonal plasticity of the avian song control system. J Neurobiol 32:426-442.

Smith GT, Brenowitz EA, Wingfield JC. 1997b. Seasonal changes in the size of the avian song control nucleus HVc defined by multiple histological markers. J Comp Neurol 381:253-261.

Smith GT, Brenowitz EA, Beecher MD, Wingfield JC. 1997c. Seasonal changes in testosterone, neural attributes of song control nuclei, and song structure in wild songbirds. J Neurosci 17:6001-6010.

Sohrabji F, Nordeen KW, Nordeen EJ. 1989. Projections of androgen-accumulating neurons in a nucleus controlling avian song. Brain Res 488:253-259.

Sohrabji F, Nordeen EJ, Nordeen KW. 1990. Selective impairment of song learning following lesions of a forebrain nucleus in the juvenile Zebra Finch. Behav Neural Biol 53:51-63.

Stokes TM, Leonard CM, Nottebohm F. 1974. The telencephalon, diencephalon, and mesencephalon of the canary, Serinus canaria in stereotaxic coordinates. J Comp Neurol 156:337-374.

Tramontin AD, Wingfield JC, Brenowitz PA. 1999. Contributions of social cues and photoperiod to seasonal plas- ticity in the adult avian song control system. J Neurosci 19:476-483.

Vallet E, Kreutzer M, Gahr M. 1996. Testosterone induces sexual release quality in the song of female canaries. Ethology 102:617-628.

Vanson A, Arnold AP, Schlinger BA. 1996. 3 $\beta$-Hydroxysteroid dehydrogenase $/ \Delta^{5}-\Delta^{4}$ isomerase and aromatase activity in primary cultures of developing zebra finch telencephalon: dehydroepiandrosterone as a substrate for synthesis of androstenedione and estrogens. Gen Comp Endocrinol 102:342-350.

Vicario DS, Simpson HB. 1995. Electrical stimulation of forebrain nuclei elicits learned vocal patterns in songbirds. J Neurophysiol 73:2602-2607.

Walters MJ, Collado D, Harding CF. 1991. Oestrogenic modulation of singing in male Zebra Finches: differential effects on directed and undirected songs. Anim Behav 42:445-452.

Wild JM. 1997. Neural pathways for the control of birdsong production. J Neurobiol 33:653-670.

Wingfield JC. 1984. Environmental and endocrine control of reproduction in the Song Sparrow, Melospiza melodia. I. Temporal organization of the breeding cycle. Gen Comp Endocrinol 56:406-416.

Wingfield JC, Farner DS. 1978a. The annual cycle of plasma irLH and steroid hormones in feral populations of the White-crowned Sparrow, Zonotrichia leucophrys gambelii. Biol Reprod 19:1046-1056.

Wingfield JC, Farner DS. 1978b. The endocrinology of a natural breeding population of the White-crowned Sparrow (Zonotrichia leucophrys pugetensis). Physiol Zool 51:188-205. 